\title{
THE EFFECT OF CREATIVITY LEARNING MODEL TOWARD LEARNING MOTIVATION AND SCIENCE PROCESSING SKILL OF FOURTH GRADE STUDENTS IN SCIENCE COURSE
}

\author{
Kadek Suardani $^{1}$, I Gusti Ayu Tri Agustiana ${ }^{2}$, Ignatius I Wayan Suwatra ${ }^{3}$ \\ ${ }^{1,2,3}$ Universitas Pendidikan Ganesha, Singaraja, Indonesia \\ Iayusuardani598@gmail.com, ${ }^{2}$ triagustiana.pgsdundiksha@gmail.com, ${ }^{3}$ wayansuwatra@yahoo.com
}

\begin{abstract}
Growing learning motivation and science processing skill are very difficult because of limited learning time at school which result in the application of learning motivation and science processing skill less than optimal. Through application creativity learning model, it is expected to be able to achieve the objectives of this research which is to analyze creativity learning model toward learning motivation and science processing skill. This research classified into quasi-experimental and the design was non-equivalent post-test only control group. All fourth-grade students belonged to the population, contained 8 classes with 184 students. Technique for sample selection was random sampling and got experimental class with 31 students and control class with 30 students. Research instrument consist of questionnaire and essay test. Manova test was used to analyze the data and continue with LSD test. From the reseach, the result showed the significant effect toward learning motivation and science processing skill that proven by significance score 0.000 that means less than 0.05 then Ho is rejected and based on LSD test, $\Delta \mu$ was less than LSD.. The findings portrayed learning motivation and science processing skill positively influenced by creativity learning model. Creativity learning model is suitable for dealing with low learning motivation and science processing skills and would be problem solving about learning especially in the use of learning model.
\end{abstract}

Keywords: creativity learning, motivation, science processing skills

\section{PENGARUH MODEL PEMBELAJARAN CREATIVITY LEARNING TERHADAP MOTIVASI BELAJAR DAN KETERAMPILAN PROSES SAINS SISWA KELAS IV PADA MATA PELAJARAN IPA}

\begin{abstract}
ABSTRAK
Sangat sulit untuk menumbuhkan motivasi belajar begitu juga dengan keterampilan proses sains karena keterbatasan waktu pembelajaran di sekolah sehingga mengakibatkan pengembangan motivasi belajar dan keterampilan proses sains siswa kurang optimum. Melalui penggunaan model Creativity Learning diharapkan mampu mencapai target penelitian, yakni menganalisis pengaruh Creativity Learning kepada motivasi belajar serta keterampilan proses sains siswa. Penelitian ini tergolong ke dalam Quasi experiment dan rancangannya adalah non-equivalent post-test only control group. Seluruh siswa kelas IV menjadi populasi penelitian, yang meliputi 8 kelas dan jumlahnya adalah 184 siswa. Pengambilan sampel dilaksanakan dengan random sampling dan didapatkan kelas eksperimen dengan total 31 siswa serta kelas kontrol dengan total 30 siswa. Instrumen penelitian terdiri atas kuesioner dan tes esay. Uji Manova digunakan untuk menganalisis data hasil penelitian, kemudian dilanjutkan dengan uji LSD. Dari penelitian yang telah dilaksanakan, memperlihatkan bahwa terdapat perubahan yang signifikan kepada motivasi belajar dan keterampilan proses sains siswa, dibuktikan oleh nilai signifikansi 0.000 , yang bermakna lebih kecil dari 0.05 , akibatnya $\mathrm{H}_{0}$ ditolak dan berdasarkan uji LSD didapatkan nilai $\Delta \mu$ lebih kecil dari LSD. Dapat disimpulkan model Creativity Learning mempengaruhi motivasi belajar begitu juga dengan keterampilan proses sains secara positif. Model pembelajaran Creativity Learning cocok diterapkan untuk mengatasi masalah motivasi belajar dan keterampilan proses sains dan menjadi pemecahan masalah tentang pembelajaran khususnya untuk penggunaan model pembelajaran.
\end{abstract}

Kata Kunci: creativity Learning, motivasi, keterampilan proses sains

\begin{tabular}{|c|c|c|}
\hline Submitted & Accepted & Published \\
\hline 04 Juni 2020 & 15 Juli 2020 & 23 Juli 2020 \\
\hline
\end{tabular}

\begin{tabular}{|l|c|c|}
\hline Citation & $:$ & $\begin{array}{r}\text { Suardani, K., Agustiana, I.G.A.T., \& Suwatra, I.I.W. (2020). The Effect of Creativity Learning Model toward Learning } \\
\text { Motivation and Science Processing Skill of Fourth Grade Students in Science Course. Jurnal PAJAR } \\
\text { (Pendidikan dan Pengajaran), 4(4), 724-737. DOI : http://dx.doi.org/10.33578/pjir.v4i2.8042. }\end{array}$ \\
\hline
\end{tabular}

\section{PENDAHULUAN}

Ilmu Pengetahuan Alam (IPA) atau Sains merupakan salah satu mata pelajaran wajib yang ada di jenjang sekolah dasar. Pada jenjang sekolah dasar hal yang harus diutamakan adalah mengembangkan rasa ingin tahu siswa (Susanto, 2013). Mengembangkan rasa ingin tahu siswa 
memerlukan dorongan dari dalam diri siswa itu sendiri, dorongan dari dalam diri seseorang disebut motivasi (Agustiana, dkk., 2019). Pembelajaran IPA di sekolah dasar bukan hanya tentang menguasai materi pembelajaran yang berupa fakta-fakta, konsep-konsep, atau prinsipprinsip saja tetapi juga merupakan suatu proses penemuan. IPA merupakan ilmu pengetahuan yang didapat dari pendekatan terhadap alam yang dilakukan secara sistematis, kontinuitas, dan objektif (Sulthon, 2016). Menurut Mete \& Jariyah (2020) tujuan pembelajaran IPA di sekolah dasar adalah agar siswa mampu bersikap ilmiah serta meningkatkan keterampilan proses dan produk. Menurut Dionisius, dkk, (2019) dalam pembelajaran IPA siswa harus aktif dalam pembelajaran melalui percobaan, pengamatan, maupun bereksperimen sehingga akan terbentuk kreativitas dan kesadaran untuk menjaga kestabilan alam. Pembelajaran IPA memiliki beberapa kompetensi yang harus dicapai oleh peserta didik, yaitu IPA sebagai produk, IPA sebagai proses, dan IPA sebagai sikap sehingga pembelajaran IPA mengarahkan siswa untuk mencapai kompetensi-kompetensi tersebut. Pembelajaran IPA di sekolah dasar hendaknya dilakukan penyelidikan-penyelidikan sederhana yang berbasis proses sehingga dapat mencakup ketiga kompetensi IPA (Yuliani, dkk., 2017). Penguasaan IPA melalui pembelajaran secara teoritis ditentukan oleh kemampuan siswa dalam menguasai keterampilan proses sains, sehingga siswa yang menguasi keterampilan proses sains dengan bagus maka prestasi akademiknya juga bagus (Dionisius, 2019). Tujuan pembelajaran dapat tercapai apabila dalam pembelajaran menerapkan strategi yang baik dan sesuai dengan karakteristik siswa serta materi (Sriwahyuni, 2020).

Pada kenyataannya, mewujudkan pembelajaran IPA yang sesuai dengan harapan dan rancangan merupakan hal yang tidak mudah. Apabila berkaca dari hasil tes PISA, kualitas pendidikan Indonesia dalam bidang sains cenderung memprihatinkan. PISA (Programme for International Students Assesment) sendiri merupakan sebuah program yang diiniasi oleh negara-negara yang tergabung dalam OECD
(Organisation for Economic Cooperation and Development), terdiri atas tes literasi dasar dalam bidang membaca, matematika, dan sains tanpa melihat pada kurikulum nasional. Khusus untuk pendidikan sains pada tahun 2018, Indonesia berada pada peringkat ke-71 dari 79 negara partisipan. Fakta tersebut menunjukkan bahwa kualitas dan kuantitas pendidikan masyarakat Indonesia khususnya dalam bidang sains cenderung jauh dari yang diharapkan (OECD, 2019).

Berdasarkan hasil wawancara dengan guru-guru kelas IV SD di Gugus I Kecamatan Buleleng dan hasil observasi di kelas, yang dilaksanakan pada tanggal 25-31 Oktober 2019 pelaksanaan pembelajaran di sekolah belum sepenuhnya sesuai dengan kurikulum 2013 yang menuntut siswa aktif selama proses pembelajaran dan belum sesuai dengan karakteristik siswa yang belum dapat berpikir abstrak. Pada saat proses pembelajaran guru belum terbiasa menerapkan model pembelajaran inovatif dan cenderung menggunakan metode ceramah, tanya jawab, dan penugasan. Penyebab guru belum terbiasa menerapkan model pembelajaran yang inovatif adalah karena kurangnya wawasan dan keterampilan guru untuk menerapkan model pembelajaran inovatif yang dapat membuat siswa aktif selama proses pembelajaran. Selama proses pembelajaran siswa terlihat kurang fokus dan tidak memiliki motivasi untuk belajar, siswa cenderung hanya menghafal materi yang diberikan, dan siswa terlihat belum menguasai aspek-aspek keterampilan proses sains padahal keterampilan proses sains sangat dibutuhkan dalam pembelajaran IPA. Berdasarkan hasil pencatatan dokumen terhadap nilai keterampilan proses IPA tema 1, dapat diketahui bahwa dari jumlah siswa 184 orang dengan KKM 68-70, 69 siswa tuntas dan 115 siswa tidak tuntas dengan rata-rata nilai 63-66 dengan itu dapat dikatakan bahwa nilai keterampilannya belum tuntas. Persentase siswa yang tuntas adalah $37.5 \%$ dan persentase siswa yang tidak tuntas adalah $62.5 \%$. Permasalahan tersebut harus segera ditangani, apabila tidak segera ditangani tentu akan menyebabkan menurunnya kualitas sumber daya manusia dan 
tidak mampu mengimbangi perkembangan Ilmu pengetahuan dan teknologi.

Berbagai upaya telah dilakukan oleh para ahli pendidikan untuk meningkatkan motivasi belajar dan keterampilan proses sains siswa. Terdapat beberapa penelitian yang berfokus pada peningkatan motivasi belajar pada mata pelajaran IPA, yakni: menggunakan model pembelajaran kooperatif tipe jigsaw (Kresnajaya, dkk.,, 2015), menggunakan model pembelajaran Contextual Teaching and Learning (Alpian dkk., 2019), melalui model pembelajaran kooperatif tipe Teams Games Tournament (Hakim \& Syofyan, 2017), melalui model Problem Based Learning (Suari, 2018). Penggunaan berbagai model pembelajaran tersebut masih menunjukkan bahwa motivasi belajar siswa belum meningkat dengan optimal karena dalam proses pembelajaran aspirasi siswa belum dapat tersampaikan secara optimal. Terdapat pula beberapa penelitian yang berfokus pada peningkatan keterampilan proses sains siswa, yakni: mengunakan model pembelajaran kooperatif tipe Group Investigation (Wahyuni, dkk., 2018), menggunakan model pembelajaran inkuiri terbimbing (Metaputri \& Garminah, 2016), melalui penggunaan model pembelajaran Problem Based Learning (Novita, dkk., 2014). Penggunaan berbagai model pembelajaran tersebut menunjukkan bahwa siswa masih memiliki hambatan dalam memahami proses sains, karena sains merupakan subjek yang kompleks dan memiliki banyak konsep yang abstrak (Agustiana, dkk., 2020). Hal tersebut menjadi hambatan karena karakteristik siswa sekolah dasar yang belum mampu berpikir abstrak dengan baik.

Menurut (Wote, dkk., 2020) keberhasilan belajar siswa dipengaruhi oleeh faktor internal yaitu motivasi dan faktor eksternal yaitu lingkungan, sekolah, keluarga, dan masyarakat. Masalah rendahnya motivasi belajar dan keterampilan proses sains siswa tersebut perlu dicarikan solusi agar pembelajaran yang dilaksanakan dapat memberikan hasil yang optimal dan mampu meningkatkan motivasi belajar dan keterampilan proses sains siswa. Berdasarkan pertimbangan dari penelitian sebelumnya, solusi yang dapat ditawarkan untuk mengatasi rendahnya motivasi belajar dan keterampilan proses sains siswa adalah dengan menggunakan model pembelajaran Creativity Learning. Model pembelajaran Creativity Learning diekstrak dari tiga model pembelajaran inovatif yang berpusat pada siswa seperti PBL, BBL, dan Inquiri. Menurut Agustiana, dkk. (2019) model pembelajaran Creativity Learning menciptakan lingkungan belajar yang membebaskan siswa untuk mengemukakan pendapat, bertanya, membuat konklusi dan jawaban tanpa merasa malu dan takut pembelajaran, suasana belajar di kelas menjadi menyenangkan dan bermakna karena melibatkan siswa secara aktif dan kreatif dalam menemukan permasalahan dan cara penyelesaianya sehingga siswa termotivasi untuk belajar. Model pembelajaran Creativity Learning juga bertujuan untuk meningkatkan pemahaman konten sains, meningkatkan pemahaman konten sains dapat diperoleh dengan mengembangkan keterampilan proses sains, sehingga dalam penerapannya model pembelajaran Creativity Learning dapat membantu untuk mengembangkan keterampilan proses sains siswa melalui penerapan sintak-sintak model pembelajaran Creativity Learning. Sasaran dari sintak model pembelajaran Creativity Learning yakni: (1) pada tahap awal pembelajaran difokuskan untuk memberikan orientasi, (2) adanya penggalian ide-ide kreatif sehingga meningkatkan keterampilan berpikir kreatif siswa, (3) kegiatan penyelidikan untuk memecahkan masalah melalui keterampilan proses sains, (4) siswa saling bertukar pikiran melalui kegiatan elaborasi, (5) kegiatan menyajikan hasil karya melatih keterampilan berkomunikasi, (6) kegiatan evaluasi sebagai refleksi pembelajaran, (7) kegiatan implementasi bertujuan agar siswa dapat menerapkan ilmu yang didapat dalam kehidupan sehari-hari (Agustiana, dkk., 2019). Semua sintak model pembelajaran Creativity Learning sangat relevan untuk meningkatkan motivasi belajar dan keterampilan proses sains siswa.

Kebaruan model pembelajaran Creativity Learning dibandingkan model pembelajaran inovatif lainnya adalah (1) dapat meningkatkan motivasi belajar siswa karena siswa terlibat aktif dalam pembelajaran dan terbebas dari kritikan tajam, (2) meningkatkan kemampuan siswa 
melakukan percobaan karena terdapat sintak penyelidikan, (3) dapat meningkatkan kemampuan menginterpretasi karena melalui kegiatan elaborasi dan pemecahan masalah, (4) siswa dapat belajar untuk menilai dan membuat masalah baru setelah pembelajaran, (5) mampu mengoptimalkan keterampilan proses sains siswa melalui sintaksintak model pembelajaran Creativity Learning. Berdasarkan masalah dan penjabaran mengenai

\section{METODE PENELITIAN}

Penelitian ini dilaksanakan dilaksanakan pada siswa kelas IV SD Negeri 1 Banyuning dan siswa kelas IV SD Negeri 8 Banyuning. Adapun waktu pelaksanaan penelitian ini dilaksanakan dari pada semester genap tahun pelajaran 2019/2020 dari bulan Oktober 2019 sampai bulan Maret 2020. Penelitian ini merupakan penelitian eksperimen semu (quasi experiment). Sugiyono (2014:114) menyatakan bahwa "Quasi-eksperimental design, digunakan karena pada kenyataannya sulit mendapatkan kelompok kontrol yang digunakan untuk penelitian". Desain penelitian ini adalah Non-Equivalent Post-test Only Control Group Design.

Populasi dalam penelitian ini adalah semua siswa kelas IV di SD Gugus I Kecamatan Buleleng, Kabupaten Singaraja tahun pelajaran 2019/2020 yang berjumlah 8 Sekolah Dasar dengan total 184 siswa. Populasi penelitian harus dalam keadaan setara, maka dari itu perlu dilakukan uji kesetaraan dengan menggunakan analisis varians satu jalur (Anava A) dengan bantuan SPSS 17.0 for Window. Berdasarkan uji kesetaraan yang telah dilakukan, diketahui bahwa signifikansi nilai hasil keterampilan IPA tema 1 sebesar 0.490. Nilai sig. $0.490>0.05$, dapat disimpulkan bahwa tidak terdapat perbedaan yang signifikan nilai keterampilan IPA tema 1 semester ganjil siswa kelas IV SD di Gugus 1 Kecamatan Buleleng tahun pelajaran 2019/2020. Hal ini berarti, setiap anggota populasi yakni seluruh siswa kelas IV SD di Gugus I Kecamatan Buleleng, Kabupaten Singaraja adalah setara atau model pembelajaran Creativity Learning, maka perlu dilakukan kajian lebih mendalam untuk menganalisis pengaruh model pembelajaran Creativity Learning terhadap motivasi belajar dan keterampilan proses sains siswa pada mata pelajaran IPA. Penelitian ini dilakukan pada siswa Kelas IV di SD Gugus I Kecamatan Buleleng Tahun Pelajaran 2019/2020.

homogen. Berdasarkan hasil uji kesetaraan dapat dilihat bahwa semua sekolah dasar di Gugus I Kecamatan Buleleng, Kabupaten Singaraja dapat menjadi sampel penelitian. Sebelum menentukan sampel, populasi dimasukkan ke dalam kelas-kelas sebagai intact group. Tahapan selanjutnya adalah menentukan sampel penelitian dengan teknik random sampling (sampel acak), yaitu pengambilan kelas secara acak tanpa pilih-pilih. Sampel penelitian ditentukan dengan melakukan pengundian. Sampel yang dipakai dalam penelitian ini adalah siswa kelas IV SD N 1 Banyuning yang berjumlah 31 siswa sebagai kelas eksperimen dan siswa dan siswa kelas IV SD N 8 Banyuning yang berjumlah 30 siswa sebagai kelas kontrol. Kelas eksperimen diberikan perlakuan dengan penerapan model pembelajaran Creativity Learning, sedangkan kelas kontrol tidak diberikan perlakuan atau pembelajaran seperti biasa yang dilakukan oleh guru.

Data yang dikumpulkan pada penelitian ini adalah data motivasi belajar dan data keterampilan proses sains. Data motivasi belajar IPA dikumpulkan dengan menggunakan metode non tes yaitu kuesioner yang terdiri dari 30 butir pernyataan. Kuesioner yang digunakan terdiri dari pernyataan positif dan negatif, serta telah lulus uji validitas isi yang dianalisis dengan menggunakan perhitungan Gregori, uji validitas butir yang dianalisis dengan teknik korelasi product moment, uji reliabilitas yang dianalisis dengan rumus Alpha Croncback. Kisi-kisi kuesioner motivasi belajar dapat dilihat pada Tabel 1. 
Tabel 1. Kisi-kisi Kuesioner Motivasi Belajar IPA

\begin{tabular}{llccc}
\hline Variabel & \multicolumn{1}{c}{ Indikator } & Item & Jumlah \\
& & Positif & Negatif & \\
\hline Motivasi & Tekun dalam belajar & $1,2,4$ & 3,5 & 5 \\
Belajar & Ulet dalam menghadapi kesulitan & 7,8 & 6 & 3 \\
& Menunjukkan minat dalam belajar & $9,11,13$ & 10,12 & 5 \\
& Mandiri dalam belajar. & 14,15 & 16,17 & 4 \\
& Dapat mempertahankan pendapatnya & 18,20 & 19,21 & 4 \\
& Tidak mudah melepas hal yang diyakini & 22,25 & 23,24 & 4 \\
& Senang mencari dan memecahkan masalah & $26,27,29$ & 28,30 & 5 \\
\hline
\end{tabular}

Pilihan skala untuk kuesioner motivasi belajar terdiri dari 5 pilihan skala yaitu Sangat Setuju (SS), Setuju (S), Ragu-ragu (RR), Tidak Setuju (TS), dan Sangat Tidak Setuju (STS). Skor penilaian kuesioner motivasi belajar untuk pernyataan positif dan negatif dapat dilihat pada Tabel 2.

Data keterampilan proses sains dikumpulkan dengan metode tes yaitu tes essay yang terdiri dari 10 butir pertanyaan. Tes yang digunakan merupakan tes yang telah lulus uji validitas isi yang dianalisis dengan menggunakan perhitungan Gregori, uji validitas butir yang dianalisis dengan teknik korelasi product moment, uji reliabilitas yang dianalisis dengan rumus Alpha Croncback, uji tingkat kesukaran, dan uji daya pembeda. Kisi-kisi tes keterampilan proses sains dapat dilihat pada Tabel 2.

Tabel 2. Kisi-kisi Tes Keterampilan Proses Sains

\begin{tabular}{lcc}
\hline \multicolumn{1}{c}{ Indikator Soal } & Aspek KPS & No Soal \\
\hline $\begin{array}{l}\text { Mengidentifikasi aktivitas sehari-hari yang memerlukan gaya dan yang } \\
\text { tidak memerlukan gaya }\end{array}$ & Observasi & 1 \\
$\begin{array}{l}\text { Mengidentifikasi manfaat gaya dalam kehidupan sehari-hari } \\
\text { Membedakan listrik statis dan listrik dinamis }\end{array}$ & Observasi & 2 \\
Mengklasifikasikan benda magnetik dan non magnetik & Klasifikasi & 3 \\
Membuat rancangan percobaan tentang listrik statis & Klasifikasi & 5 \\
Membuat rancangan percobaan tentang pengaruh gaya terhadap terhadap & Eksperimen & 7 \\
gerak suatu benda & & 9 \\
Menafsirkan jumlah kutub magnet & Interpretasi \\
Menafsirkan pengaruh gaya gravitasi terhadap benda di bumi & Interpretasi & 6 \\
Menyebutkan peng aruh gaya terhadap terhadap gerak suatu benda & Komunikasi & 8 \\
Menyimpulkan hubungan antara tekstur permukaan benda dengan gaya & Komunikasi & 10 \\
gesek melalui grafik & & \\
\hline
\end{tabular}

Data hasil penelitain didapat melalui post test, dianalisis secara bertahap, yaitu dengan analisis statistik deskriptif dan statistik inferensial. Data dianalisis dengan statistik deskriptif untuk menggambarkan penyebaran data dengan mengitung mean dan standar deviasi kemudian yang dikonversikan dengan Pedoman Acuan Ideal Teoritis (PAIT). 


\section{Tabel 3. Kriteria Pedoman Acuan Ideal Teoritis (PAIT)}

\begin{tabular}{cc}
\hline Kriteria & Klasifikasi \\
\hline $\mathrm{X}_{\mathrm{i}}+1,5 \mathrm{SD}_{\mathrm{i}} \leq \mathrm{M}<\mathrm{X}_{\mathrm{i}}+3,0 \mathrm{SD}_{\mathrm{i}}$ & Sangat Baik \\
$\mathrm{X}_{\mathrm{i}}+0,5 \mathrm{SD}_{\mathrm{i}} \leq \mathrm{M}<\mathrm{X}_{\mathrm{i}}+1,5 \mathrm{SD}_{\mathrm{i}}$ & Baik \\
$\mathrm{X}_{\mathrm{i}}-0,5 \mathrm{SD}_{\mathrm{i}} \leq \mathrm{M}<\mathrm{X}_{\mathrm{i}}+0,5 \mathrm{SD}_{\mathrm{i}}$ & Cukup \\
$\mathrm{X}_{\mathrm{i}}-1,5 \mathrm{SD}_{\mathrm{i}} \leq \mathrm{M}<\mathrm{X}_{\mathrm{i}}-0,5 \mathrm{SD}_{\mathrm{i}}$ & Tidak Baik \\
$\mathrm{X}_{\mathrm{i}}-3,0 \mathrm{SD}_{\mathrm{i}} \leq \mathrm{M}<\mathrm{X}_{\mathrm{i}}-1,5 \mathrm{SD}_{\mathrm{i}}$ & Sangat Tidak Baik \\
\hline
\end{tabular}

Untuk membuat rentang skor, maka Mi dan SDi dihitung menggunakan rumus sebagai berikut.

$\mathrm{M}_{\mathrm{i}}=\frac{1}{2}$ (skor maksimal ideal + skor minimal ideal $)$ $\mathrm{SD}_{\mathrm{i}}=\frac{1}{6}($ skor maksimal ideal - nilai minimal ideal $)$

Sebelum dilakukan uji hipotesis, terlebih dahulu dilakukan uji prasyarat. Uji prasyarat yang dilakukan adalah uji normalitas dengan uji Kolmogorov-Smirnov dan Shapiro-Wilk dengan sigifikansi 0,05 , uji homogenitas varian dengan uji Levene's test of Equality of Error Varians dengan signifikansi 0,05 , dan uji korelasi antar variabel terikat dengan uji product moment dengan taraf signifikan $5 \%$. Setelah uji prasyarat terpenuhi, maka dilanjutkan dengan uji hipotesis. Uji hipotesis penelitian menggunakan statistik inferensial yaitu melalui uji MANOVA dengan bantuan SPSS-17 for windows dengan taraf signifikan 5\%. Tindak lanjut uji MANOVA adalah uji signifikan nilai rata-rata antar kelompok dengan menggunakan Least Significant Difference (LSD).

\section{HASIL DAN PEMBAHASAN}

\section{Data Motivasi Belajar IPA Siswa Kelas IV SD}

Data motivasi belajar IPA siswa kelas IV SD diperoleh dari hasil nilai post-test. Deskripsi hasil penelitian data motivasi belajar siswa memaparkan banyak siswa, skor maksimun, skor

minimum, mean, dan standar deviasi. Pada Tabel 4, disajikan rekapitulasi hasil perhitungan statistik deskriptif post-test skor motivasi belajar IPA kelas eksperimen dan kelas kontrol.

Tabel 4. Rekapitulasi Hasil Perhitungan Statistik Deskritif Post-test Skor Motivasi Belajar IPA Kelas Eksperimen dan Kelas Kontrol

\begin{tabular}{ccc}
\hline Statistik Deskriptif & Post-test \\
& Eksperimen & Kontrol \\
\hline Banyak siswa $(n)$ & 31 & 30 \\
Skor maksimum & 144 & 102 \\
Skor minimum & 115 & 75 \\
Mean & 131.58 & 87.30 \\
Standar deviasi & 8.130 & 7.809 \\
\hline
\end{tabular}

Berdasarkan Tabel 4, nilai motivasi belajar IPA (post-test) kelompok eksperimen adalah mean $=131.58$ dan standar deviasi $=8.130$; sedangkan pada kelompok kontrol diperoleh mean $=87.30$ dan standar deviasi $=7.809$. Dapat disimpulkan bahwa rata-rata motivasi belajar Sains post-test kelompok eksperimen lebih tinggi dari rata-rata nilai motivasi siswa kelompok kontrol.

Tinggi rendahnya variabel post-test motivasi belajar siswa dapat diketahui melalui skor rata-rata motivasi belajar siswa yang dikonversikan dengan menggunakan kriteria Pedoman Acuan 
Penilaian Teoritis (PAIT). Setelah dikonversikan dengan menggunakan kriteria PAIT, rata-rata siswa pada kelompok eksperimen adalah 131.58; maka nilai motivasi belajar siswa setelah dibelajarkan menggunakan model pembelajaran Creativity Learning berada pada kategori "sangat baik" yaitu pada rentangan 120-150. Sedangkan, untuk kelompok kontrol yang menggunakan yang dibelajarkan tanpa model pembelajaran Creativity Learning memiliki nilai rata-rata 87.30 berada pada kategori "cukup" yaitu pada rentangan 80 100.

\section{Data Keterampilan Proses Sains Siswa Kelas IV SD}

Data keterampilan proses Sains siswa kelas IV SD diperoleh dari hasil nilai post-test. Deskripsi hasil penelitian data keterampilan proses Sains memaparkan banyak siswa, skor maksimum, skor minimum, mean, dan standar deviasi. Pada Tabel 5, disajikan rekapitulasi hasil perhitungan statistik deskriptif post-test skor keterampilan proses Sains kelas eksperimen dan kelas kontrol berikut.

Tabel 5. Rekapitulasi Hasil Perhitungan Statistik Deskritif Post-test Skor Keterampilan Proses Sains Kelas Eksperimen dan Kelas Kontrol

\begin{tabular}{ccc}
\hline Statistik Deskriptif & Eksperimen & Post-test \\
& 31 & Kontrol \\
\hline Banyak siswa $(n)$ & 36 & 30 \\
Skor maksimum & 25 & 30 \\
Skor minimum & 31.35 & 19 \\
Mean & 3.115 & 23.63 \\
Standar deviasi & & 3.275 \\
\hline
\end{tabular}

Berdasarkan Tabel 5, nilai keterampilan proses Sains (post-test) kelas eksperimen adalah mean $=31.35$ dan standar deviasi $=3.115$; sedangkan pada kelas kontrol diperoleh mean $=$ 23.63 dan standar deviasi $=3.275$. Berdasarkan data tersebut, disimpulkan bahwa rata-rata nilai keterampilan proses Sains kelas eksperimen lebih tinggi dari rata-rata nilai keterampilan proses Sains siswa kelas kontrol.

Tinggi rendahnya variabel post-test keterampilan proses Sains siswa dapat diketahui melalui skor rata-rata keterampilan proses Sains siswa yang dikonversikan dengan menggunakan kriteria Pedoman Acuan Penilaian Teoritis (PAIT). Setelah dikonversikan dengan menggunakan kriteria PAIT, rata-rata post-test siswa pada kelas eksperimen adalah 31.35; maka nilai keterampilan proses Sains siswa setelah dibelajarkan menggunakan model pembelajaran Creativity Learning berada pada kategori "baik" yang terletak pada rentangan 27.5-32.5. Sedangkan, untuk kelas kontrol yang tidak menggunakan model pembelajaran Creativity Learning memiliki nilai rata-rata 23.63 berada pada kategori "cukup", yaitu pada rentangan 22.5-27.5.

\section{Uji Normalitas Sebaran Data}

Berikut ini akan dirangkum hasil uji normalitas data motivasi belajar dan data keterampilan proses Sains siswa kelas IV SD seperti pada Tabel 6. 
Tabel 6. Hasil Uji Normalitas Sebaran Data Motivasi dan Keterampilan Proses Sains

\begin{tabular}{cccccccc}
\hline Variabel & Kelompok & \multicolumn{2}{c}{ Kolmogorov-Smirnov } & \multicolumn{3}{c}{ Shapiro-Wilk } \\
& & Taraf & Hasil Sig. & Keputusan & Taraf & Hasil Sig. & Keputusan \\
& & Sig. & & & Sig. & & Normal \\
Motivasi & Eksperimen & 0.05 & 0.200 & Normal & 0.05 & 0.142 & Normal \\
Belajar & Kontrol & 0.05 & 0.200 & Normal & 0.05 & 0.307 & Normal \\
Keterampilan & Eksperimen & 0.05 & 0.192 & Normal & 0.05 & 0.152 & Normal \\
Proses Sains & Kontrol & 0.05 & 0.200 & Normal & 0.05 & 0.138 & \\
\hline
\end{tabular}

Berdasarkan hasil pengujian normalitas pada Tabel 6, motivasi belajar IPA pada kelas eksperimen adalah $0.200>0.05$; sedangkan kelas kontrol adalah $0.200>0.05$; yang berarti data motivasi belajar siswa kelas IV SD yang diuji dengan menggunakan uji KolmogorovSmirnov berdistribusi normal. Uji Shapiro Wilk nilai signifikansi motivasi belajar pada kelas eksperimen $0.142>0.05$; sedangkan kelas kontrol $0.307>0.05$; yang berarti motivasi belajar siswa kelas IV SD yang diuji dengan menggunakan uji Shapiro Wilk berdistribusi normal. Sehingga dapat disimpulkan motivasi belajar siswa kelas IV SD pada kelas kontrol maupun kelas eksperimen berdistribusi normal.

Pada uji Kolmogorov-Smirnov, nilai signifikansi keterampilan proses Sains siswa kelas IV SD pada kelas eksperimen adalah $0.192>0.05$; sedangkan kelas kontrol adalah $0.200>0.05$; yang berarti data keterampilan proses Sains siswa kelas
IV SD yang diuji dengan menggunakan uji Kolmogorov-Smirnov berdistribusi normal. Uji Shapiro Wilk nilai signifikansi keterampilan proses Sains pada kelas eksperimen adalah $0.152>0.05$; sedangkan kelas kontrol adalah $0.138>0.05$; yang berarti keterampilan proses Sains siswa kelas IV SD yang diuji dengan menggunakan uji Shapiro Wilk berdistribusi normal. Sehingga dapat disimpulkan data keterampilan proses Sains siswa kelas IV SD pada kelas eksperimen maupun kelas kontrol berdistribusi normal.

\section{Uji Homogenitas Varian}

Uji homogenitas varians yang digunakan adalah uji Levene's test of Equality of Error Varians. Pada Tabel 7 berikut ini akan disajikan rangkuman hasil uji homogenitas varian untuk motivasi belajar dan keterampilan proses Sains pada kelas eksperimen dan kelas kontrol.

Tabel 7. Hasil Uji Homogenitas Kelompok Eksperimen dan Kontrol

\begin{tabular}{cccc}
\hline Variabel & Taraf Signifikan & Hasil Signifikansi & Keputusan \\
\hline Motivasi & 0.05 & 0.820 & Homogen \\
Keterampilan Proses & 0.05 & 0.708 & Homogen \\
Sains & & & \\
\hline
\end{tabular}

Berdasarkan Tabel 7, nilai signifikansi motivasi belajar siswa kelas IV SD yaitu $0.820>$ 0.05 ; yang berarti, data motivasi belajar IPA siswa kelas IV SD memiliki varians yang homogen. Nilai signifikansi keterampilan proses Sains siswa kelas IV SD yaitu $0.708>0.05$; yang berarti, data keterampilan proses Sains siswa kelas IV SD pada kelas eksperimen dan kelas kontrol memiliki varians yang homogen.

\section{Uji Korelasi Antar Variabel Terikat}

Uji korelasi dalam penelitian ini dilakukan pada 2 data yaitu 1) motivasi belajar IPA dan keterampilan proses sains pada siswa kelas IV yang menggunakan model pembelajaran Creativity Learning dan 2) motivasi belajar IPA dan keterampilan proses sains pada siswa kelas IV yang tidak menggunakan model pembelajaran Creativity Learning. 
Tabel 8. Hasil Uji Korelasi Antar Variabel Terikat

\begin{tabular}{lccc}
\hline \multicolumn{1}{c}{ Kelompok Data } & $\mathbf{r}_{\mathbf{x y}}$ hitung & $\mathbf{r}_{\mathbf{x y}}$ table & Keterangan \\
\hline Korelasi antar variabel terikat eksperimen & 0.000 & 0.367 & Tidak berkorelasi \\
Korelasi antar variabel terikat kontrol & 0.000 & 0.374 & Tidak berkorelasi \\
\hline
\end{tabular}

Berdasarkan Tabel 8, korelasi antar variabel terikat pada kelas eksperimen yaitu motivasi belajar IPA dan keterampilan proses sains dengan menggunakan uji product moment menunjukkan $\mathrm{r}_{\mathrm{xy}}$ hitung sebesar 0.000 dengan $\mathrm{N}=$ 31 dan $\mathrm{df}=29$; sehingga di dapat $\mathrm{r}_{\mathrm{xy}}$ tabel $=0.367$. Hal ini berarti $\mathrm{r}_{\mathrm{xy}}$ hitung $(0.000)<$ rxy tabel (0.367). Berdasarkan hasil perhitungan tersebut, dapat disimpulkan bahwa antara variabel motivasi belajar IPA dan keterampilan proses sains pada kelompok eksperimen tidak berkorelasi. Pada kelas kontrol, hasil perhitungan tersebut menunjukkan rxy hitung sebesar 0.000; dengan $\mathrm{N}=30$ dan $\mathrm{df}=$ 28 , sehingga di dapat $\mathrm{r}_{\mathrm{xy}}$ tabel $=0.374$. Hal ini berarti $\mathrm{r}_{\mathrm{xy}}$ hitung $(0.00)<\mathrm{r}_{\mathrm{xy}}$ tabel (0.374). Berdasarkan hasil perhitungan tersebut, dapat disimpulkan bahwa antara variabel motivasi belajar IPA dan keterampilan proses sains pada kelompok eksperimen tidak berkorelasi.

\section{Uji Hipotesis Penelitian}

Berdasarkan hasil uji prasyarat (uji normalitas, uji homogenitas varians, dan uji korelasi antar variabel terikat), dapat disimpulkan bahwa data yang dipakai dalam penelitian ini dapat dilanjutkan untuk digunakan dalam pengujian hipotesis. Terdapat tiga hipotesis yang diuji dengan analisis MANOVA dan dilanjutkan dengan uji Least Significant Different (LSD) untuk menganalisis signifikansi perbedaan motivasi belajar dan keterampilan proses sains siswa kelas eksperimen dan siswa kelas kontrol.

Hipotesis pertama dianalisis dengan analisis Manova dengan menggunakan Test of Between Subject Effects yang dibantu dengan SPSS 17.0 for windows, berdasarkan hasil uji Test of Between Subject Effects dapat diketahui bahwa nilai signifikansi kelas pada motivasi belajar adalah $0.000<0.05$ yang berarti $\mathrm{H}_{0}$ ditolak dan $\mathrm{H}_{1}$ diterima. Sehingga dapat ditarik kesimpulan bahwa terdapat pengaruh yang signifikan model pembelajaran Creativity Learning terhadap motivasi belajar siswa kelas IV pada mata pelajaran IPA di SD Gugus I Kecamatan Buleleng Tahun Pelajaran 2019/2020. Selanjutnya untuk menganalisis signifikansi perbedaan motivasi belajar IPA siswa yang dibelajarkan dengan model pembelajaran Creativity Learning dan yang tidak dibelajarkan dengan model pembelajaran Creativity Learning diuji dengan metode Least Significant Different (LSD). Berdasarkan hasil perhitungan diperoleh batas penolakan LSD = 4.043. Kriteria motivasi belajar IPA siswa berbeda secara signifikan apabila $|\Delta \mu|>$ LSD. Rangkuman hasil uji signifikansi perbedaan motivasi belajar IPA siswa disajikan dalam Tabel 9.

Tabel 9. Signifikansi Perbedaan Motivasi Belajar IPA

\begin{tabular}{ccccc}
\hline $\begin{array}{c}\text { Variabel } \\
\text { Dependen }\end{array}$ & Perlakuan & (1) & $\Delta \boldsymbol{\mu}$ & Sig \\
\hline $\begin{array}{c}\text { Motivasi } \\
\text { Belajar } \\
\text { IPA }\end{array}$ & $\begin{array}{c}\text { Tanpa Model Creativity } \\
\text { Learning } \\
\text { Model Creativity } \\
\text { Learning }\end{array}$ & $\begin{array}{c}\text { Model Creativity } \\
\text { Learning }\end{array}$ & -44.28 & 0.000 \\
& Tanpa Model Creativity & 44.28 & 0.000 \\
\hline
\end{tabular}

Berdasarkan Tabel 9, harga mutlak $\Delta \mu=$ 44.28, dengan angka signifikan 0.000. Angka sigifikan lebih kecil dari 0.05 dan $\Delta \mu$ lebih besar dari LSD, berarti motivasi belajar IPA siswa yang dibelajarkan dengan model pembelajaran Creativity Learning secara signifikan lebih tinggi 
dibandingkan dengan yang diajar tanpa model Creativity Learning.

Hipotesis kedua dianalisis dengan analisis Manova dengan menggunakan Test of Between Subject Effects yang dibantu dengan SPSS 17.0 for windows, berdasarkan hasil uji Test of Between Subject Effects dapat diketahui bahwa nilai signifikansi kelas pada keterampilan proses sains adalah $0.000<0.05$ yang berarti $\mathrm{H}_{0}$ ditolak dan $\mathrm{H}_{1}$ diterima. Sehingga dapat ditarik kesimpulan bahwa terdapat pengaruh yang signifikan model pembelajaran Creativity Learning terhadap keterampilan proses sains siswa kelas IV pada mata pelajaran IPA di SD Gugus I Kecamatan
Buleleng Tahun Pelajaran 2019/2020. Selanjutnya untuk menganalisis signifikansi perbedaan keterampilan proses sains siswa yang dibelajarkan dengan model pembelajaran Creativity Learning dan yang tidak dibelajarkan dengan model pembelajaran Creativity Learning diuji dengan metode Least Significant Different (LSD). Berdasarkan hasil perhitungan diperoleh batas penolakan LSD $=1.649$. Kriteria keterampilan proses sains siswa berbeda secara signifikan apabila $|\Delta \mu|>$ LSD. Rangkuman hasil uji signifikansi perbedaan keterampilan proses sains siswa disajikan dalam Tabel 10.

Tabel 10. Signifikansi Perbedaan Keterampilan Proses Sains

\begin{tabular}{ccccc}
\hline $\begin{array}{c}\text { Variabel } \\
\text { Dependen }\end{array}$ & $\begin{array}{c}(\mathbf{1}) \\
\text { Perlakuan }\end{array}$ & $\begin{array}{c}(\mathbf{2}) \\
\text { Perlakuan }\end{array}$ & $\Delta \boldsymbol{\mu}$ & Sig \\
\hline $\begin{array}{c}\text { Keterampilan } \\
\text { Proses Sains }\end{array}$ & $\begin{array}{c}\text { Tanpa Model } \\
\text { Creativity } \\
\text { Learning } \\
\text { Model Creativity } \\
\text { Learning }\end{array}$ & $\begin{array}{c}\text { Model Creativity } \\
\text { Learning }\end{array}$ & -7.72 & 0.000 \\
& $\begin{array}{c}\text { Tanpa Model } \\
\text { Creativity Learning }\end{array}$ & 7.72 & 0.000 \\
\hline
\end{tabular}

Berdasarkan Tabel 10, harga mutlak $\Delta \mu=$ 7.72, dengan angka signifikan 0.000. Angka signifikan lebih kecil dari 0.05 dan $\Delta \mu$ lebih besar dari LSD, berarti keterampilan proses sains siswa

\section{Pembahasan}

Keberhasilan model pembelajaran Creativity Learning terhadap motivasi belajar IPA siswa disebabkan oleh beberapa hal. Pertama, model pembelajaran Creativity Learning membuat suasana belajar di kelas menjadi menyenangkan. Hal tersebut sesuai dengan pendapat Agustiana, dkk. (2019) yaitu model pembelajaran Creativity Learning menciptakan lingkungan belajar yang membebaskan siswa untuk mengemukakan pendapat, bertanya, membuat konklusi dan jawaban tanpa merasa malu dan takut. Siswa juga terbebas dari kritikan tajam yang dapat menjatuhkan semangat belajar siswa. Suasana belajar yang menyenangkan dapat membuat siswa tertarik dan semangat dalam belajar sehingga siswa merasa termotivasi untuk belajar. Hal tersebut sejalan dengan pendapat Sumantri (2015) yang dibelajarkan dengan model pembelajaran Creativity Learning secara signifikan lebih tinggi dibandingkan yang diajar tanpa model Creativity Learning.

yang menyatakan bahwa motivasi siswa akan terlihat apabila proses pembelajaran menyenangkan. Kedua, model pembelajaran Creativity Learning membuat pembelajaran menjadi bermakna, selama proses pembelajaran siswa dilibatkan secara aktif untuk memecahkan permasalahan dan pembelajaran juga dikaitkan dengan situasi nyata, sehingga ilmu yang didapatkan siswa dapat diterapkan dalam kehidupannya masing-masing. Sejalan dengan pendapat Suparta, dkk. (2015) yang menyatakan bahwa pembelajaran yang bermakna dapat memicu aktivitas siswa untuk belajar sehingga motivasi belajarnya dapat meningkat. Ketiga, siswa belajar secara berkelompok dan siswa kesempatan untuk bertukar pikiran dengan temannya dan bisa mengemukakan ide-idenya, 
mencari informasi lebih mendalam untuk mendukung pendapat yang disampaikannya agar pendapatnya dapat diakui kebenarannya. Hal tersebut dapat meningkatkan motivasi belajar siswa karena siswa dapat menyelesaikan masalah secara berkelompok. Sejalan dengan pendapat Alpian, dkk. (2019) yang menyatakan bahwa motivasi belajar siswa dapat meningkat apabila pembelajaran dilakukan secara berkelompok sehingga dapat menyelesaikan masalahnya. Keempat, model pembelajaran Creativity Learning dapat meningkatkan rasa ingin tahu siswa, pada fase orientasi guru memberikan permasalahan yang autentik sehingga rasa ingin tahu siswa bangkit. Hal tersebut sejalan dengan sintaks model Creativity Learning yaitu pada fase orientasi, pada fase orientasi kegiatan guru adalah membangkitkan rasa ingin tahu siswa melalui demonstrasi dan pemberian masalah autentik yang berkaitan dengan materi yang akan dipelajari (Agustiana, dkk., 2019). Temuan-temuan ini juga didukung oleh hasil penelitian Devi, dkk. (2014) yang menunjukkan terdapat perbedaan yang signifikan motivasi belajar IPA antara siswa yang belajar dengan menggunakan model berbasis masalah dengan kelompok siswa yang belajar dengan menggunakan model pembelajaran konvensional dalam pembelajaran IPA karena siswa mampu menggali masalah-masalah dalam kehidupan sehari-hari dan melakukan pemecahan masalah. Penelitian yang dilakukan oleh Agustiana, dkk. (2020) menunjukkan bahwa terdapat perbedaan yang signifikan motivasi belajar siswa terhadap mata pelajaran IPA apabila siswa mendapatkan perlakuan model pembelajaran yang memberikan mereka ruang lebih aktif dalam memecahkan masalah mereka sendiri secara kritis dan kreatif. Berdasarkan penelitian yang telah dilakukan dan diperkuat oleh beberapa pendapat di atas, dapat disimpulkan bahwa model pembelajaran Creativity Learning dapat meningkatkan motivasi belajar siswa.

Pada konteks keterampilan proses sains, keberhasilan pembelajaran dengan model pembelajaran Creativity Learning terhadap keterampilan proses sains disebabkan oleh beberapa hal. Temuan ini sejalan dengan Agustiana, dkk. (2019), yang menyatakan bahwa model pembelajaran Creativity Learning bertujuan untuk meningkatkan pemahaman konten sains, meningkatkan pemahaman konten sains dapat diperoleh dengan mengembangkan keterampilan proses sains; sehingga dalam penerapannya, model pembelajaran Creativity Learning dapat membantu untuk mengembangkan keterampilan proses sains siswa. Pertama, fase penyelidikan mampu melatih siswa untuk mengumpulkan fakta yang relevan, mengklasifikasikan, menentukan alat dan bahan, menentukan langkah kegiatan dan menginterpretasi. Hal ini sejalan dengan pendapat Agustiana, dkk. (2019) bahwa fase penyelidikan mengkondisikan peserta didik menggali ide kreatif dengan melakukan penyelidikan sehingga menemukan fakta-fakta sebagai bentuk jawaban permasalahan dalam kerja kelompok. Kedua, fase elaborasi mampu melatih siswa untuk mengklasifikasikan, berkomunikasi, menginterpretasi, dan membuat laporan percobaan, pada fase ini siswa membuat laporan percobaan penyelidikan dengan membangun nilainilai kerjasama, melatih kemampuan berkomunikasi, mengemukakan pendapat, mempertahankan pendapat, dan mengumpulkan informasi melalui diskusi. Pada fase elaborasi siswa berdiskusi dengan temannya secara berkelompok, pembelajaran secara berkelompok dapat meningkatkan keterampilan siswa dalam berkomunikasi. Hal tersebut sejalan dengan pendapat Wahyuni (2018) bahwa diskusi kelompok dapat melatih keketerampilan proses sains yaitu aspek berkomunikasi dan menginterpretasi. Ketiga, fase menyajikan hasil karya mampu melatih kemampuan berkomunikasi siswa melalui presentasi, pada fase ini siswa mempresentasikan hasil karyanya dalam diskusi terbuka. Sejalan dengan pendapat Novita, dkk. (2014) bahwa diskusi terbuka dapat meningkatkan keterampilan siswa berkomunikasi. Temuan ini diperkuat juga oleh Hidayah \& Pujiastuti (2016) yang menemukan bahwa pembelajaran berbasis masalah berpengaruh signifikan terhadap keterampilan proses sains siswa karena keterampilan proses sains dilatih dengan memecahkan masalah. Penelitian yang dilakukan oleh Handika \& Wangid (2013) menunjukkan bahwa pembelajaran berbasis masalah 
berpengaruh signifikan dan lebih baik dibandingkan dengan pembelajaran konvensional terhadap keterampilan proses sains siswa dalam hal mengamati, mengelompokkan, mengukur/ menghitung, memprediksi, menyimpulkan dan mengomunikasikan. Pembelajaran berbasis masalah membuat siswa bisa mencari solusi dari masalah tersebut melalui keterampilan proses sains. Berdasarkan penelitian yang telah dilakukan dan diperkuat oleh beberapa pendapat di atas, dapat disimpulkan bahwa model pembelajaran Creativity Learning dapat meningkatkan keterampilan proses sains.

Model pembelajaran Creativity Learning membuat pembelajaran menjadi bermakna. Pada proses pembelajaran siswa dilibatkan secara aktif dalam menemukan permasalahan dan cara penyelesaiannya. Cara untuk menyelesaikan

\section{SIMPULAN DAN REKOMENDASI}

Berdasarkan hasil pengujian hipotesis dan pembahasan, maka dapat ditarik simpulan bahwa model pembelajaran Creativity Learning dapat meningkatkan motivasi belajar dan keterampilan proses sains siswa kelas IV pada mata pelajaran IPA di SD Gugus I Kecamatan Buleleng Tahun Pelajaran 2019/2020 yang dibuktikan dari hasil uji Test Of Between-Subjects Effects didapatkan nilai signifikan motivasi sebesar 0.000 dan lebih kecil dari 0.05 dan berdasarkan uji Least Significant Different $(L S D)$ didapatkan nilai $\Delta \mu$ lebih besar dari LSD. Berdasarkan temuan-temuan dalam penelitian ini, dapat disampaikan saran-saran sebagai berikut. Kepada guru disarankan untuk menggunakan model pembelajaran Creativity Learning dalam pembelajaran karena model

\section{DAFTAR PUSTAKA}

Agustiana, I. G. A. T, dkk. (2019). Model Pembelajaran OPPEMEI. Undiksha Press.

Agustiana, I. G. A. T., dkk. (2020). Efektivitas Model OPPEMEI untuk Meningkatkan Kemampuan Berpikir Kreatif Mahasiswa. Journal of Education Technology, 4(2), 150-159. Tersedia pada masalahnya didapat melalui mengembangkan keterampilan proses sains. Kelas eksperimen yang dibelajarkan dengan model pembelajaran Creativity Learning menunjukkan hasil yang lebih baik yaitu sebagian besar siswa sudah aktif dalam memecahkan suatu permasalahan dengan ide-ide kreatifnya, mengeksplorasi berbagai sumber agar bisa mendapatkan fakta-fakta untuk mendukung ide kreatifnya, siswa mampu mengklasifikasikan data dan fakta yang diperoleh secara runtut, siswa mampu merancang percobaan, siswa mampu menafsirkan jawaban yang dapat menyelesaikan permasalahan, dan siswa percaya diri mempresentasikan hasil percobannya di depan kelas. Berdasarkan hal tersebut, model pembelajaran Creativity Learning dapat meningkatkan motivasi belajar dan keterampilan proses sains siswa.

pembelajaran ini sudah terbukti dapat meningkatkan motivasi belajar dan keterampilan proses sains siswa. Kepada kepala sekolah hendaknya dapat menciptakan kondisi yang mampu mendorong para guru untuk mencoba menerapkan model pembelajaran Creativity Learning dalam pembelajaran IPA khususnya dan mata pelajaran lain pada umumnya dalam upaya meningkatkan motivasi belajar dan keterampilan proses sains. Peneliti lain dapat menjadikan penelitian ini sebagai kajian empiris untuk pengembangan penelitian lanjutan mengenai model pembelajaran Creativity Learning secara lebih luas dan mendalam agar dapat membawa kontribusi positif dan menjadi acuan dalam pengembangan ilmu pengetahuan.

https://ejournal.undiksha.ac.id/index.php/J ET/article/view/25343

Alpian, dkk. (2019). Pengaruh Model Pembelajaran Contextual Teaching and Learning (CTL) terhadap Motivasi Belajar Siswa. Jurnal BASICEDU, 3(3), 894-900. Tersedia 
Jurnal PAJAR (Pendidikan dan Pengajaran)

Volume 4 Nomor 4 Juli 2020 | ISSN Cetak : 2580 - 8435 | ISSN Online : 2614 - 1337

DOI : http://dx.doi.org/10.33578/pjr.v4i2.8042

http://www.jbasic.org/index.php/basicedu/ article/view/174

Devi, N. L. H. Y., Rasana, I. D. P. R., \& Suwatra, I. I. W. (2014). Pengaruh Model Pembelajaran Problem Based Learning terhadap Motivasi Belajar IPA Siswa Kelas V SD di Gugus I Kecamatan Buleleng. MIMBAR PGSD Undiksha, 2(1). Tersedia pada https://ejournal.undiksha.ac.id/index.php/J JPGSD/article/view/2292

Dionisius, I. M. K., Margunayasa, I. G., \& Kusmariyatni, N. N. (2019). Pengaruh Model Pembelajaran Pogil terhadap Keterampilan Proses Sains. MIMBAR PGSD Undiksha, 7(3), 271-278. Tersedia pada

https://ejournal.undiksha.ac.id/index.php/J JPGSD/article/view/19464.

Hakim, S. A., \& Syofyan, H. (2017). Pengaruh Model Pembelajaran Kooperatif Tipe Teams Games Tournament (TGT) terhadap Motivasi Belajar IPA di Kelas IV SDN Kelapa Dua 06 Pagi Jakarta Barat. International Journal of Elementary Education, 1(4), 249-263. Tersedia pada https://ejournal.undiksha.ac.id/index.php/I JEE/article/view/12966

Handika, I., \& Wangid, M. N. (2013). Pengaruh Pembelajaran Berbasis Masalah Terhadap Penguasaan Konsep dan Keterampilan Proses Sains Siswa Kelas V. Jurnal Prima Edukasia, 1(2), 85-93. Tersedia pada https://journal.uny.ac.id/index.php/jpe/arti cle/view/2320

Hidayah, R., \& Pujiastuti, P. (2016). Pengaruh PBL Terhadap Keterampilan Proses Sains dan Hasil Belajar Kognitif IPA pada Siswa SD. Jurnal Prima Edukasia, 4(2), 186197. Tersedia pada https://journal.uny.ac.id/index.php/jpe/arti cle/view/7789

Kesnajaya, I. K., dkk. (2015). Pengaruh Model Pembelajaran Kooperatif Tipe Jigsaw Terhadap Motivasi Belajar dan Hasil Belajar IPA Siswa Kelas V Pada SD Negeri 3 Tianyar Barat. e-Journal Program Pasca Sarjana Universitas Pendidikan Ganesha, 5, 1-9. Tersedia pada

https://www.neliti.com/publications/12466 2/pengaruh-model-pembelajaran-

kooperatif-tipe-jigsaw-terhadap-motivasibelajar-dan

Metaputri, N. K., \& Garminah, N. N. (2016). Pengaruh Model Pembelajaran Inkuiri Terbimbing dan Minat Belajar Terhadap Keterampilan Proses Sains pada Siswa Kelas IV SD. Jurnal Pendidikan dan Pengajaran, 49(2), 89-97. Tersedia pada https://ejournal.undiksha.ac.id/index.php/J JPGSD/article/view/7402

Mete, Y. Y., \& Jariyah, A. (2020). The Application of Make a Match Learning Model in Improving Student Learning Outcomes in Science. JURNAL PAJAR (Pendidikan dan Pengajaran), 4(2), 323329. Tersedia pada http://dx.doi.org/10.33578/pjr.v4i2.7921.

Novita, G. A. D. L., Sudana, D. N., Riastini, P. N. (2014). Pengaruh Model Pembelajaran PBL Terhadap Keterampilan Proses Sains Siswa Kelas V SD DI Gugus IV Diponegoro Kecamatan Mendoyo. MIMBAR PGSD Undiksha, 2(1). Tersedia pada

https://ejournal.undiksha.ac.id/index.php/J JPGSD/article/view/2823

OECD. (2019). Programme For International Student Assesment (PISA) Result From PISA 2018. OECD, 1-3, 1-10. Tersedia pada http://www.oecd.org/pisa/

Sriwahyuni, E. (2020). Keefektifan Model Pembelajaran Problem Based Learning Terhadap Motivasi dan Hasil Belajar. Journal of Education Technologi, 4(1), 80-87. Tersedia pada https://ejournal.undiksha.ac.id/index.php/J ET/article/view/24101

Suari, N. P. (2018). Penerapan Model Pembelajaran Problem Based Learning untuk Meningkatkan Motivasi Belajar IPA. Jurnal Ilmiah Sekolah Dasar, 2(3), 241-247. Tersedia pada https://ejournal.undiksha.ac.id/index.php/J ISD/article/view/16138

Sulthon. (2016). Pembelajaran IPA yang Efektif dan Menyenangkan Bagi Siswa Madrasah 
Jurnal PAJAR (Pendidikan dan Pengajaran)

Volume 4 Nomor 4 Juli 2020 | ISSN Cetak : 2580 - 8435 | ISSN Online : 2614 - 1337

DOI : http://dx.doi.org/10.33578/pjr.v4i2.8042

Ibtidaiyah (MI). Elementary, 4(1), 38-54.

Tersedia

pada

http://repository.iainkudus.ac.id/1562/

Sumantri, M. S. (2015). Strategi Pembelajaran

Teori dan Praktik di Tingkat Pendidikan

Dasar. Jakarta: Rajawali Press.

Suparta, D. G., Lasmawan, I. W., \& Marhaeni, A.

A. I. N. (2015). Pengaruh Model Pembelajaran Kooperatif Teknik Make A Match Terhadap Motivasi Belajar dan Hasil Belajar IPS. e-Journal Program Pasca Sarjana Undiksha, 5, 1-12. Tersedia pada https://www.neliti.com/publications/12457 7/pengaruh-model-pembelajarankooperatif-teknik-make-a-match-terhadapmotivasi-bel

Sugiyono. (2014). Metode Penelitian Pendidikan Pendekatan Kuantitatif, Kualitatif, dan $R \& D$. Bandung: CV Alfabeta.

Susanto, A. (2013). Teori Belajar dan Pembelajaran di Sekolah Dasar. Jakarta:Kencana Prenada Media Group.

Wahyuni, N. L. P. W., Wibawa, I. M. C., \& Renda, N. T. (2018). Pengaruh Model Pembelajaran Kooperatif Tipe Group Investigation Berbantuan Asesmen Kinerja Terhadap Keterampilan Proses Sains. International Journal of Elementary Education. 2(3), 202-210. Tersedia pada https://ejournal.undiksha.ac.id/index.php/I JEE/article/view/15959

Wote, A. Y. V., Sasingan, M., \& Kitong, O. E. (2020). Efektivitas Penggunaan Model Quantum Teaching dalam Meningkatkan Hasil Belajar IPA. Journal of Education Technology, 4(2), 96-102. Tersedia pada https://ejournal.undiksha.ac.id/index.php/J ET/article/view/24369

Yuliani, N. P., Margunayasa, G., \& Parmiti, D. P. (2017). Pengaruh Model Pembelajaran POGIL Berbantuan Peta Pikiran Terhadap Hasil Belajar IPA Siswa Kelas V SD. Journal of Education Technology, 1(2), 117-123. Tersedia pada https://ejournal.undiksha.ac.id/index.php/J ET/article/view/11773 